\title{
Antenatal teaching of the use of seat belts in pregnancy
}

\author{
Malcolm Griffiths, Martin McD Usherwood, \\ Philip W Reginald
}

\section{Departments of \\ Obstetrics and}

Gynaecology, Wexham

Park Hospital, Slough,

Berkshire SL2 4HL

Malcolm Griffiths, MRCOG, registrar

Philip W Reginald, MRCOG, consultant

Departments of Obstetrics and Gynaecology, Stoke Mandeville Hospital,

Aylesbury,

Buckinghamshire

Martin McD Usherwood,

FRCOG, consultant

Correspondence to:

Dr M Griffiths, Department

of Obstetrics and

Gynaecology, Royal

Berkshire Hospital,

Reading, Berkshire

RG1 5AN.

BMF 1992;304:614
Road traffic accidents are the commonest cause of blunt maternal trauma in pregnancy. ${ }^{1}$ In the United Kingdom it is compulsory for motorists and passengers to wear seat belts unless they have a medical exemption certificate. Some pregnant women find seat belts uncomfortable and do not wear them, others wear them incorrectly. We recently reported two cases showing the hazards to the fetus of ill fitting restraints. ${ }^{2}$ Aware that pregnant women may not know how to wear seat belts correctly, we surveyed the teaching of seat belt use in antenatal classes.

\section{Patients and methods}

We sent a postal questionnaire regarding child restraints and seat belts in pregnancy to antenatal teachers in 30 randomly chosen maternity units in England and Wales. Questionnaires were sent before it became compulsory for adults to wear seat belts in the rear of vehicles. Respondents were asked what advice was given either routinely or when requested and whether they would ever advise a woman to seek an exemption certificate.

Twenty four units $(80 \%)$ replied. Twenty one units gave teaching regarding child restraints, but only 11 gave advice about seat belts. In all units where no teaching was given teachers felt able to advise. No teachers advised women not to wear a seat belt or to travel only as a rear seat passenger; seven teachers advised wearing a seat belt but if too uncomfortable to travel unrestrained in the rear; eight advised wearing the belt "in the usual way"; six advised modifying the belt's position; three suggested a combination of the above. Sensibly some teachers questioned whether women who couldn't wear a seat belt should drive.

When modifications were recommended, most suggested that the belt should "fit comfortably." Three respondents used different modifications-one to "fit the bump," one to pad the belt with a folded towel or foam, and the third to use the diagonal strap alone.

No teacher believed that either the mother or her fetus would be safest if a seat belt was avoided. Despite this 10 said they might advise a pregnant woman to obtain an exemption certificate; one respondent reported being advised by the local police that pregnant women were exempt from seat belt regulations.

\section{Comment}

A properly fitted restraint protects motorists and passengers in an accident, and prevents seat belt injury to abdominal viscera. Conventional seat belts restrain a passenger by the skeleton. The diagonal strap should pass over the shoulder and chest (between the breasts) without impinging on the abdomen; the lap strap should lie across the upper thighs restraining the femurs or pelvis or both, thus avoiding visceral injury. For pregnant women the basic rule is that straps should be above and below the bump not over it (R Cummins, Royal Society for the Prevention of Accidents, personal communication). ${ }^{3}$ Padding the seat belt is potentially dangerous as this might slip and render the belt less effective. Use of the diagonal strap alone is extremely dangerous.

Little attention is given in antenatal classes to wearing of seat belts. When advice is given it is not necessarily appropriate. Teachers need to know the correct advice to give. Correct use of seat belts could be simply taught by demonstration or by using a video. If maternal and fetal safety are emphasised women are likely to heed the advice in both the current and any subsequent pregnancy.

We are grateful for the cooperation of the midwives and thank Robert Cummins and other members of the Royal Society for Prevention of Accidents National Road Safety Committee for advice.

1 Rothenberger D, Quattlebaum FW, Perry JF, Zabel J, Fischer RP. Blun maternal trauma: a review of 103 cases. F Trauma 1978;18:173-9.

2 Griffiths M, Hillman G, Usherwood MMcD. Seat belt injury in pregnancy resulting in fetal death: two case reports. Brf Obstet Gynaecol 1991;98:320-1. 3 Herbert DC. Use of seat belts during pregnancy. Med f Aust 1982;2:115.

(Accepted 11 November 1991)
Many of us have been reading with righteous indignation and horror Mr. George Kennan's graphic descriptions of the cruelties practised in the prisons of Siberia. This indignation will, however, it may be hoped, extend to what was revealed as to the treatment of prisoners in police cells in this country in the Walsall Police Court on Friday, January 8th. After the examination there of the alleged anarchists, one of them named Charles complained that he did not get enough to eat, and that there were no rugs to cover them the previous night, upon which the Chief Constable said that they would only have bread and water sufficient to keep them alive as long as they were under remand, but afterwards the county authorities would maintain them. Of course, they might have whatever they liked to pay for at the present time. The three prisoners accused of anarchical conspiracy had just been remanded for one week when the Chief Constable of Staffordshire is alleged to have made this statement, so if he is correctly reported-and we quote from the Times' report - they are at present, being poor and unable to contribute to their own maintenance, undergoing discipline of a very rigorous description. It would be incredible, were it not reported upon such high police authority, that persons charged with crime in this country, but assumed to be innocent until convicted, are, because without means, left without sufficient coverings in this inclement weather and maintained upon a bare subsistence dietary of bread and water It is to be remembered that accused persons, whether innocent or guilty, labour under anxiety and other depressing emotions, and are therefore peculiarly liable to be injuriously affected by cold and partial starvation. There can be no doubt that permanent injury to health may be done by a regimen such as that which the alleged anarchists at Walsall are now being submitted to. Not long ago a Commission reported on the condition of police cells in England, and described many of them as being in a filthy and insanitary state and altogether unfit for even animal habitation. It would be interesting to know what steps have been taken to remedy the defects and abuses exposed by the Commission. The whole question of the treatment of prisoners awaiting trial urgently demands the consideration of Parliament. (BMF 1892;i:134) 